\title{
The Change of Taurine Transport in Osteocytes by Oxidative Stress, Hypertonicity and Calcium Channel Blockers
}

\author{
Young-Sook KANG* and Soon-Joo KIM \\ College of Pharmacy and Research Institute of Pharmaceutical Sciences, Sookmyung Women's University, Seoul, Korea
}

(Received August 2; Revised September 2; Accepted September 3)

\begin{abstract}
Taurine is the most abundant amino acid in many tissues and is found to be enhancing the bone tissue formation or inhibits the bone loss. Although it is reported that taurine reduces the alveolar bone loss through inhibiting the bone resorption, its functions of taurine and expression of taurine transporter (TauT) in bone have not been identified yet. The purpose of this study is to clarify the uptake mechanism of taurine in osteoblast using mouse osteoblast cell lines. In this study, mouse stromal ST2 cells and mouse osteoblast-like MC3T3-E1 cells as osteoblast cell lines were used. The activity of taurine uptake was assessed by measuring the uptake of $\left[{ }^{3} \mathrm{H}\right]$ taurine in the presence or absence of inhibitors. TauT mRNA was detected in ST2 and MC3T3-E1 cells. $\left[{ }^{3} \mathrm{H}\right]$ Taurine uptake by these cells was dependent on the presence of extracellular calcium ion. The $\left[{ }^{3} \mathrm{H}\right]$ taurine uptake in ST2 cells treated with $4 \mathrm{mM}$ calcium was increased by 1.7 -fold of the control which was a significant change. In contrast, in $\mathrm{Ca}^{++}$-free condition and L-type calcium channel blockers (CCBs), taurine transport to osteocyte was significantly inhibited. In oxidative stress conditions, $\left[{ }^{3} \mathrm{H}\right]$ taurine uptake was decreased by TNF- $\alpha$ and $\mathrm{H}_{2} \mathrm{O}_{2}$. Under the hyperosmotic conditions, taurine uptake was increased, but inhibited by CCBs in hyperosmotic condition. These results suggest that, in mouse osteoblast cell lines, taurine uptake by TauT was increased by the presence of extracellular calcium, whereas decreased by CCBs and oxidative stresses, such as TNF- $\alpha$ and $\mathrm{H}_{2} \mathrm{O}_{2}$.
\end{abstract}

Key words: Taurine, Taurine transporter, ST2 cell, MC3T3-E1 cell, Taurine uptake, TNF- $\alpha$, Hyperosmotic condition, Calcium channel blockers

\section{INTRODUCTION}

Taurine (2-aminoethanesulfonic acid) is conditionally essential amino acid for children, which is present in a variety of tissue and exhibits many important physiological functions such as stabilization of membranes, osmoregulation, antioxidation, and detoxification (Huxtable, 1992). In bone cells, taurine is also found in high concentration (Lubec et al., 1997), and is known to help in enhancing the bone tissue formation, which was observed by increased matrix formation and collagen synthesis (Park et al., 2001). Besides stimulating the bone tissue formation, it is suggested that being incorporated in bone tissue, taurine plays an important role in bone metabolism by inhibiting experimental bone resorp-

\footnotetext{
${ }^{*}$ Corresponding author

Tel: +82-2-710-9562, Fax: +82-2-2077-7975

E-mail: yskang@sm.ac.kr
}

tion, osteoclast formation, and osteoclast survival (Koide et al., 1999), however, this mechanism was not clarified yet.

Bones, in the state of disease, are risky to be exposed to osmotic pressure stress or inflammatory cytokines such as TNF- $\alpha$. For the patients with diabetes mellitus, they are likely to be in high osmotic pressure condition since the level of glucose in the blood is high. In the condition of high osmotic pressure, it is reported that mRNA expression of TauT, betaine transporter (BGT-1) and sodium/myo-inositol co-transporter (SMIT) is changed and uptake of taurine, betaine and myo-inositol is elevated in many tissues (Warskulat et al., 1997; Takeuchi et al., 2000; Shioda et al., 2002; El-Sherbeny et al., 2004; Warskulat et al., 2004). Moreover, there are some papers that the mRNA expression of TauT and BGT-1 and the uptake of taurine and betaine into the kidney elevated under high osmotic pressure (Uchida et al., 1992; Yamauchi et al., 1992). However, it is not yet proved that 
how the uptake of taurine is changed when bone is exposed to the state of high osmotic pressure.

Calcuim, which plays an important role in bone formation, may elevate uptake of taurine. However, the mechanism of $\mathrm{Ca}^{++}$, taurine uptake to the bone cells is not yet known. How these two factors are related to bone formation in osteoblast cell lines is the main concern in this study.

The purpose of this study is to clarify the mechanism of taurine uptake in osteoblast. In this study, we used mouse stromal ST2 cells and mouse osteoblast-like MC3T3-E1 cells. The stromal cell line ST2, which is derived from mouse bone marrow, differentiated into osteoblast-like cells in response to ascorbic acid (Otsuka et al., 1999). We investigated the expression of TauT and the effect of various factors on taurine uptake in these osteoblastic cells.

\section{MATERIALS AND METHODS}

\section{Reagent}

$\left[{ }^{2}{ }^{3} \mathrm{H}(\mathrm{N})\right]$ Taurine $\left(\left[{ }^{3} \mathrm{H}\right], 30.3 \mathrm{Ci} / \mathrm{mmol}\right)$ were purchased from NEN Life Science (Boston, MA, USA). Tumor necrosis factor- $\alpha$ (TNF- $\alpha$, human recombinant (Esherichia coll) solution, $10 \mu \mathrm{g} / \mathrm{mL}$ ) was purchased from Boehringer Mannheim Biochemica (Mannheim, Germany) and lipopolysaccharide (LPS) from Salmonella minnesota R595 (Re) was obtained from List Biological Laboratories (Campbell, CA, USA). All other chemicals were of reagent grade and commercially available.

\section{Cell culture}

ST2 cells and MC3T3-E1 cells were grown routinely in tissue culture dishes at $37^{\circ} \mathrm{C}$ under $5 \% \mathrm{CO}_{2}$ and $95 \%$ air. The cells were cultured in Dulbecco's modified Eagle's medium (DMEM; Gibco, Grand Island, NY) $100 \mathrm{U} / \mathrm{mL}$ benzylpenicillin, $100 \mu \mathrm{g} / \mathrm{mL}$ streptomycin sulfate (Gibco, Grand Island, NY), 10\% fetal bovine serum (Gibco, Grand Island, NY). The osmolality of the normal culture medium was about $280 \mathrm{mOsm} / \mathrm{kg}$. Hyperosmotic culture medium (380 mOsm $/ \mathrm{kg}$ ) was prepared by adding 100 $\mathrm{mM}$ raffinose to normal culture medium.

\section{$\left[{ }^{3} \mathrm{H}\right]$ Taurine uptake study by culture ST2 and MC3T3-E1 cells}

The $\left[{ }^{3} \mathrm{H}\right]$ taurine uptake was performed through the previous report (Kang et al. 2002). ST2 cells $\left(1 \times 10^{5}\right.$ cells/ well) and MC3T3-E1 cells $\left(1.5 \times 10^{5} \mathrm{cells} /\right.$ well) were cultured at $37^{\circ} \mathrm{C}$ for 2 days on rat tail collagen type-I coated 24-well plates (Becton Dickinson)and washed with $1 \mathrm{~mL}$ extracellular fluid (ECF) buffer consisting of $122 \mathrm{mM}$

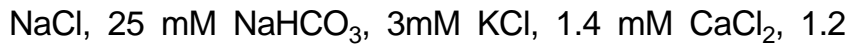
$\mathrm{mM} \mathrm{MgSO}_{4}, 0.4 \mathrm{mM} \mathrm{K}_{2} \mathrm{HPO}_{4}, 10 \mathrm{mM}$ D-glucose and 10 $\mathrm{mM}$ Hepes $(\mathrm{pH} 7.4)$ at $37^{\circ} \mathrm{C}$. Uptake was initiated by applying $200 \mu \mathrm{L}$ ECF buffer containing $0.5 \mu \mathrm{Ci}\left[{ }^{3} \mathrm{H}\right]$ taurine for water adhesion at $37^{\circ} \mathrm{C}$ in the presence or absence of inhibitors. After appropriate time periods, uptake was terminated by removing the applied solution and cells were immersed in ice-cold ECF buffer. The cells were then solubilized in $750 \mu \mathrm{L} 1 \mathrm{M} \mathrm{NaOH}$. An aliquot $(50 \mu \mathrm{L})$ was taken for protein assay using a DC protein assay kit (Bio-Rad, Hercules, CA, USA) with bovine serum albumin as a standard. The remaining solution $(500 \mu \mathrm{L})$ was mixed with $5 \mathrm{~mL}$ scintillation cocktail (Hionic-fluor, Packard, Meriden, CT, USA) for measurement of radioactivity in a liquid scintillation counter (LS6500, Beckman, Fullerton, CA, USA).

\section{Reverse transcription-polymerase chain reaction (RT-PCR) analysis}

Expression of rat taurine transporter, rat glyceraldehyde 3-phosphate dehydrogenase (G3PDH), by osteoblast cell lines was analyzed by RT-PCR analysis. The sequences of the taurine transporter (TauT) primers were as follows: sense, 5'-CTACGCGTCCATCGTCATCGTGT CC-3'; antisense, 5'-AAGTGAAGTTGGCGGCGCTAAG GGA-3'. Total RNA was isolated by the acid phenol procedure using ISOGEN (Wako Pure Chemical Industries, Ltd., Tokyo, Japan) according to the manufacturer's protocol. The first standard cDNA reaction was performed using ReverTra Ace M-MLV reverse transcriptase (Rever Tra Ace, Toyobo Co., Ltd., Osaka, Japan). RT-PCR was performed with TAKARA Ex TaqTM (Takara Shuzo Co., Ltd., Shiga, Japan) according to the manufacturer's instructions. The PCR was carried out using the following protocol. After an initial melting temperature of $85^{\circ} \mathrm{C}$ for $5 \mathrm{~min}$, primers were added as a hot start method. There was $1 \mathrm{~min}$ of denaturation at $94^{\circ} \mathrm{C}, 1 \mathrm{~min}$ of annealing at $57^{\circ} \mathrm{C}$ or $59^{\circ} \mathrm{C}$, and $1 \mathrm{~min}$ of extension at $72^{\circ} \mathrm{C}$ for repeated cycles of amplification, followed by a final extension at $72^{\circ} \mathrm{C}$ for $10 \mathrm{~min}$. The PCR products were analyzed on a $5 \%$ acrylamide gel, stained with ethidium bromide, and visualized under ultraviolet light.

\section{Statistical analysis}

All data represent mean \pm SEM values. An unpaired, two-tailed Student's t-test was used to determine the significance of differences between two group means and $p<0.05$ was considered statistically significant. 


\section{RESULTS}

\section{Effect of calcium ion on $\left.{ }^{3} \mathrm{H}\right]$ taurine uptake}

The effect on taurine uptake into osteoblast cells was examined at the $5 \mathrm{~min}$ time point under calcium-free condition (Fig. 1). Under calcium-free condition, $\left[{ }^{3} \mathrm{H}\right]$ taurine uptake was significantly reduced by $57.7 \%$ and $30.4 \%$ in ST2 cells and MC3T3-E1 cells, respectively. The uptake of $\left[{ }^{3} \mathrm{H}\right]$ taurine was not affected in the presence of $2.8 \mathrm{mM}$ (2-fold) calcium ion by ST2 cells and MC3T3-E1 cells. On the other hand, the uptake of $\left[{ }^{3} \mathrm{H}\right]$ taurine was increased in the presence of $4 \mathrm{mM}$ calcium ion by ST2 cells, but not affected by MC3T3-E1 cells. Taurine uptake was regulated by $\mathrm{Ca}^{++}$in progenitor osteoblast cells but, less in osteoblast cells.

\section{Effect of TNF- $\alpha$, LPS and $\mathrm{H}_{2} \mathrm{O}_{2}$ on [ $\left.{ }^{3} \mathrm{H}\right]$ taurine uptake}

The effect of TNF- $\alpha$, LPS and $\mathrm{H}_{2} \mathrm{O}_{2}$ treatment on $\left[{ }^{3} \mathrm{H}\right]$ taurine uptake was examined in osteoblast cell lines and results are summarized in Table I. Treatment with 10 $\mathrm{ng} / \mathrm{mL}$ LPS for $24 \mathrm{~h}$ resulted in a significant increase in $\left[{ }^{3} \mathrm{H}\right]$ taurine uptake. On the other hand, $20 \mathrm{ng} / \mathrm{mL}$ TNF- $\alpha$ for $24 \mathrm{~h}$ and $100 \mu \mathrm{M} \mathrm{H}_{2} \mathrm{O}_{2}$ for $1 \mathrm{~h}$ resulted in a significant decrease in $\left[{ }^{3} \mathrm{H}\right]$ taurine uptake. As shown in Fig. 2, TNF$\alpha$ pre-incubation, for up to $4 \mathrm{~h}$, showed increment and then decreased after $8 \mathrm{~h}$ in the $\left[{ }^{3} \mathrm{H}\right]$ taurine uptake by ST2 cells. However, in MC3T3-E1 cells, uptake increased till 8 hours, and began to decrease as 12 hours had passed.

\section{Effect on hyperosmotic conditions on $\left[{ }^{3} \mathrm{H}\right]$ taurine uptake by osteoblast cell lines}

The effect of hyperosmotic conditions on taurine transport activity was examined using osteoblast cell lines exposed to hypertonic culture medium (380 mOsm/ $/ \mathrm{kg}$ )

Table I. The effect of oxidative stress on $\left[{ }^{3} \mathrm{H}\right]$ taurine uptake by ST2 and MC3T3-E1 cells

\begin{tabular}{ccc}
\hline \multirow{2}{*}{ Treatment } & \multicolumn{2}{c}{ Uptake of $\left[{ }^{3} \mathrm{H}\right]$ taurine $(\%$ of control) } \\
\cline { 2 - 3 } & ST2 cells & MC3T3-E1 cells \\
\hline Control & $100 \pm 4$ & $100 \pm 10$ \\
TNF- $\alpha$ & $78.7 \pm 3.7^{* * *}$ & $52.0 \pm 3.0^{\star *}$ \\
$\mathrm{H}_{2} \mathrm{O}_{2}$ & $13.9 \pm 1.3^{* * *}$ & $5.17 \pm 1.34^{* * *}$ \\
LPS & $109 \pm 2^{*}$ & $124 \pm 2^{*}$ \\
\hline
\end{tabular}

$\left[{ }^{3} \mathrm{H}\right]$ Taurine $(41.3 \mathrm{nM})$ uptake was at $37^{\circ} \mathrm{C}$ for $5 \mathrm{~min}$ in the presence of taurine transporter substrates such as $20 \mathrm{ng} / \mathrm{mL}$ TNF- $\alpha, 100 \mu \mathrm{M} \mathrm{H}_{2} \mathrm{O}_{2}, 10 \mathrm{ng} / \mathrm{mL}$ LPS. Each value represents the mean \pm SEM $(n=4)$.

${ }^{*} p<0.05,{ }^{* *} p<0.01,{ }^{* *} p<0.001$; significantly different from control. for up to $24 \mathrm{~h}$. As shown in Fig. 3, TauT mRNA was increased up to $8 \mathrm{~h}$ in ST2 cells, but in MC3T3-E1 cells, resulted in an increase until 4 hours and decreased after $8 \mathrm{~h}$. Under hyperosmotic conditions, though $\left[{ }^{3} \mathrm{H}\right]$ taurine uptake decreased from $1 \mathrm{~h}$ to $12 \mathrm{~h}$, increased at $24 \mathrm{~h}$ in ST2 and MC3T3-E1 cells (Fig. 4).

\section{Effect of calcium channel blockers on $\left[{ }^{3} \mathrm{H}\right]$ taurine uptake}

To examine the effect of calcium inhibitor on $\left[{ }^{3} \mathrm{H}\right]$ taurine uptake, we used the L-type calicium channel blockers, nifedipine and verapaiml. The uptake of $\left[{ }^{3} \mathrm{H}\right]$ taurine at $5 \mathrm{~min}$ significantly inhibited in the presence of $100 \mu \mathrm{M}$ nifedipine and $100 \mu \mathrm{M}$ verapamil compared with control (Fig. 5). Also, the effect of calcium inhibitor on hyperosmotic-induced $\left[{ }^{3} \mathrm{H}\right]$ taurine uptake, $100 \mu \mathrm{M}$ nifedipine and $100 \mu \mathrm{M}$ verapamil inhibited the hyperosmotic-induced $\left[{ }^{3} \mathrm{H}\right]$ taurine uptake compared with hyperosmotic conditions (Fig. 6).

\section{DISCUSSION}

To characterize taurine transport by the osteoblast cells, $\left[{ }^{3} \mathrm{H}\right]$ taurine uptake was performed using ST2 and MC3T3-E1 cells. Under $\mathrm{Ca}^{++}$free condition, $\left[{ }^{3} \mathrm{H}\right]$ taurine uptake was significantly reduced in ST2 and MC3T3-E1 cells by $57.7 \%$ and $30.4 \%$, respectively. On the other hand, the uptake of $\left[{ }^{3} \mathrm{H}\right]$ taurine increased in the presence of $4 \mathrm{mM} \mathrm{Ca}^{++}$in ST2 cells, but not affected by MC3T3-E1 cells. As reported, taurine uptake in rat retina of original cell host was not affected under $0.1 \mathrm{mM} \mathrm{Ca}^{++}$ (Militante et al., 1999). However, in this study, taurine uptake in ST2 cell was reduced in low level of $\mathrm{Ca}^{++}$concentration while increased in $4 \mathrm{mM} \mathrm{Ca}^{++}$(2.8 times under the normal conditions) (Fig. 1). There needs to be more reviews on the relationship between taurine and $\mathrm{Ca}^{++}$ concentration. Taurine also has an effect on $\mathrm{Ca}^{++}$uptake. $\mathrm{Ca}^{++}$uptake is activated in many tissues such as heart, brain and retina, and maintains homeostasis as reported (Della et al., 2002; El Idrissi et al., 2004). It is also known that calcium plays an important role in bone formation. As taurine conductances were inhibited by L-type calcium channel blocker in rat astrocytes (Li G. et al., 2002), it is possible that change of extracellular $\mathrm{Ca}^{++}$concentration also affects the taurine uptake in osteoblast. Therefore, we examined the effect of $\mathrm{Ca}^{++}$or L-type calcium channel blocker for the $\left[{ }^{3} \mathrm{H}\right]$ taurine uptake by osteoblast cells. The effect of taurine transporter on the extracellular taurine concentration under calcium depletion increased the evoked taurine release in rat striatum (Molchanova et al., 


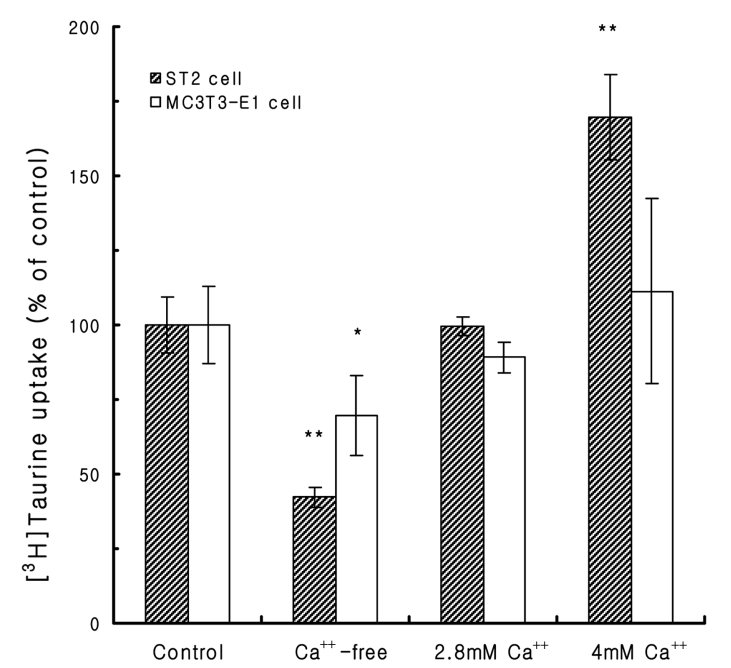

Fig. 1. Effect of calcium ion on $\left[{ }^{3} \mathrm{H}\right]$ taurine uptake ; $\left[{ }^{3} \mathrm{H}\right] \mathrm{Tau}-$ rine $(41.3 \mathrm{nM})$ uptake was at $37^{\circ} \mathrm{C}$ for 5 min under of $\mathrm{Ca}^{++}$ free and calcium ion. $\mathrm{Ca}^{++}$was replaced with $\mathrm{Mg}^{++}$. Each value represents the mean \pm SEM $(n=4)$. ${ }^{*} P<0.01$, ${ }^{* *} P<0.001$; significantly different from control.

2005). Moreover, the uptake of $\left[{ }^{3} \mathrm{H}\right]$ taurine was significantly inhibited in the presence of nifedipine and verapamil, which are L-type calcium channel blockers, compared with control in ST2 and MC3T3-E1 cells. Some reported that taurine excretion in astrocyte cell of rat is inhibited by $\mathrm{Ca}^{++}$and calmodulin inhibitor (( $\mathrm{Li} \mathrm{G}$. et al., 2002). From this study, it is supposed that inhibiting taurine uptake by calcium inhibitor is from inhibiting TauT expression. That is also because calcium inhibitor blocks reaction of $\mathrm{Ca}^{++}$and calmodulin.

Cytokine is one of the factors modulating taurine uptake. TNF- $\alpha$, an inflammatory cytokine, increases expression of TauT mRNA and intracellular taurine uptake (Kang et al., 2002; Mochizuki et al., 2002). Pre-treatment TNF- $\alpha$ increases taurine uptake more in TR-BBB13 than in rat astrocyte and human intestinal Caco-2 cells (Chang et al., 2001). In this study, taurine uptake was decreased 24 hours after pre-treatmen TNF- $\alpha$ in ST2 and MC3T3-E1 cell hosts. And so, the changes of uptake for 24 hours after pre-treatment were investigated (Fig. 2). As the result, $\left[{ }^{3} \mathrm{H}\right]$ taurine uptake in ST2 cell was increased 1 hour after pre-treatment TNF- $\alpha$ but began to decrease after that. In MC3T3-E1 cell, it was increased for 8 hours, decreased after that. Moreover, TNF- $\alpha$ pre-treatment obviously decreased $\left[{ }^{3} \mathrm{H}\right]$ taurine uptake $(22 \%$ decrease in ST2 cell, $48 \%$ decrease in MC3T3-E1 cell). As there is a report that TNF- $\alpha$ stimulation induced apoptosis in MC3T3-E1 cell (Pavalko et al., 2003), in this experiment, it can be considered that taurine uptake was relatively

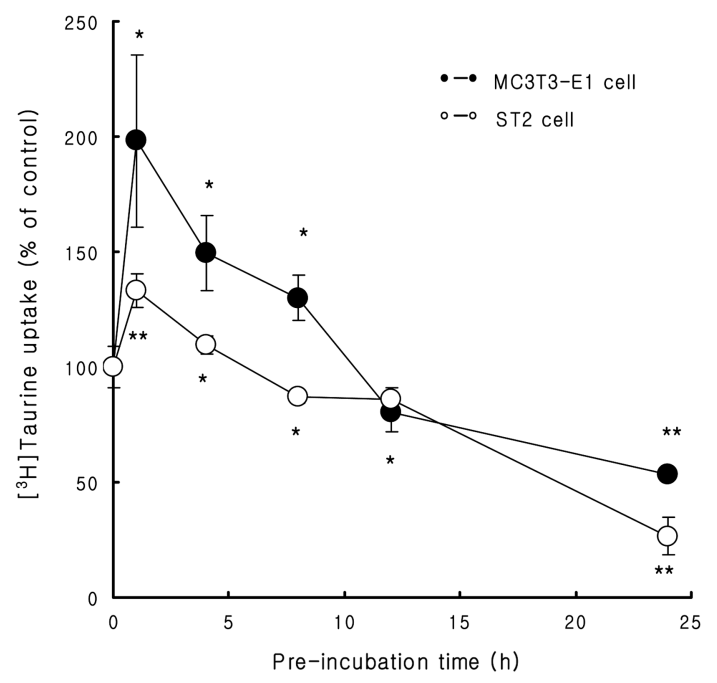

Fig. 2. $\left[{ }^{3} \mathrm{H}\right]$ Taurine uptake effect after TNF- $\alpha$ preincubation for $24 \mathrm{~h}$ in ST2 and MC3T3-E1 cells. Each point represents the mean \pm SEM $(n=4)$. ${ }^{*} P<0.01,{ }^{* *} P<0.001$; significantly different from the time $=0$.

decreased with apoptosis being induced even though taurine uptake increased as time pass.

LPS, known as an endotoxin, is reported to stimulate production of TNF- $\alpha$ and increases taurine uptake in rat astrocyte. From this experiment, taurine uptake in ST2 and MC3T3-E1 cells was increased by 24 hours after LPS pre-treatment. It is known that LPS stimulates production of many kinds of cytokines inducing TNF- $\alpha$ (Chung and Benvniste, 1990). Also, in this study, there was no increase of taurine uptake in ST2 and MC3T3-E1 cell hosts. Therefore, it is considered that the uptake of taurine increased by LPS was not influenced by TNF- $\alpha$ produced from LPS, but other cytokines or another factor. Taurine $(100 \mu \mathrm{g} / \mathrm{ml})$ suppressed the formation of these osteoclast-like cells in the presence of LPS, IL-1 $\alpha$ or PGE2 in mouse marrow cultures. Although IL-1 $\alpha$ elongated the survival of the osteoclast-like cells, taurine blocked the supportive effect of IL-1 $\alpha$ on osteoclast survival (Koide et al., 1999). In contrast, LPS decreased taurine uptake significantly in macrophage cell line, RAW 264.7 cell (Kim et al., 2003). This study suggested that LPS induced down regulation of taurine uptake in murine macrophage might be mediated via the action of nitric oxide. Therefore, the mechanism study of changes of taurine uptake by LPS is needed to be further elucidated.

Oxidative stress is another factor of modulating taurine uptake. It is known that $\mathrm{H}_{2} \mathrm{O}_{2}$ or cumene hydroperoxide which is a kind of active oxygen decreases taurine uptake (Wersinger et al., 2001). Thus, $\left[{ }^{3} \mathrm{H}\right]$ taurine uptake 

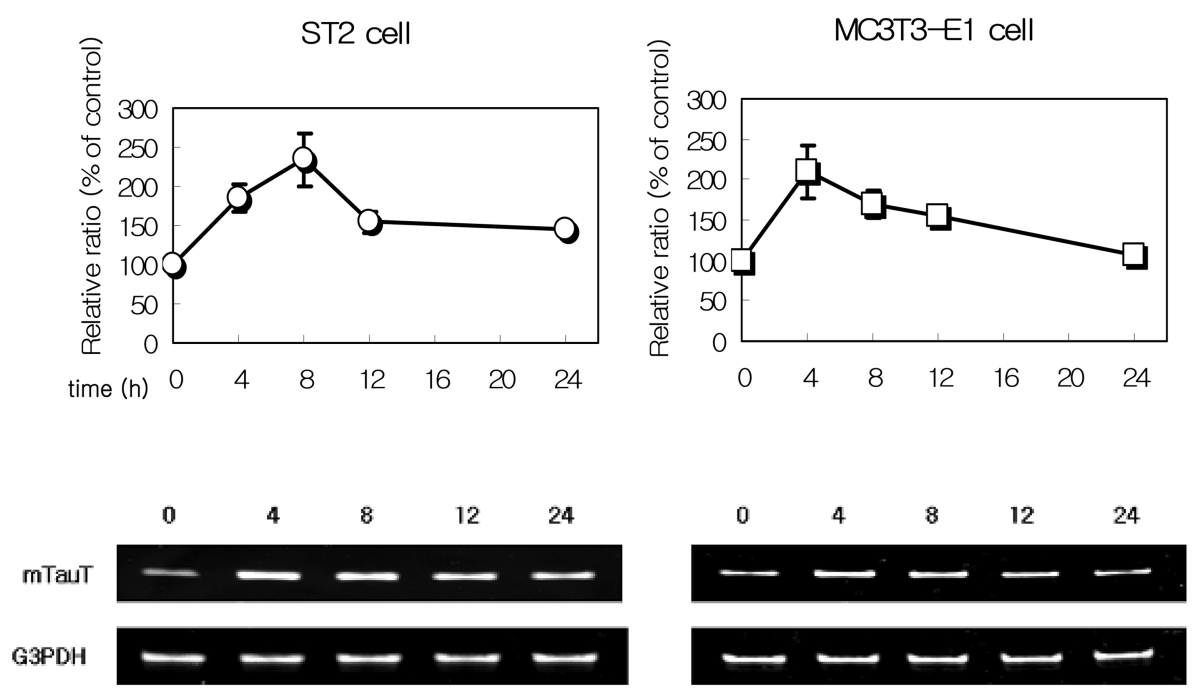

Fig. 3. Time-dependent change in TauT mRNA levels in ST2 and MC3T3-E1 exposed to hyperosmotic conditions. Cells were treated with $100 \mathrm{mM}$ raffinose. Each point represents the mean $\pm \operatorname{SEM}(n=3)$.

in ST2 cell obviously decreased by $36 \%$ compared to control by 24 hours after $\mathrm{H}_{2} \mathrm{O}_{2}$ pre-treatment. There is also a report that oxidative stress inhibits ion channel, such as $\mathrm{Na}^{+}$channel, $\mathrm{Cl}^{-}$channel and $\mathrm{Ca}^{++}$channel (Kourie, 1998). Taurine uptake is related to TauT that is dependent on $\mathrm{Na}^{+}$and $\mathrm{Cl}^{-}$, and that in ST2 cells and MC3T3-E1 cells is dependent on $\mathrm{Ca}^{++}$too. Therefore, we can suggest that decrease of taurine uptake by $\mathrm{H}_{2} \mathrm{O}_{2}$ pretreatment is because of the concentration in $\mathrm{Na}^{+}, \mathrm{Cl}^{-}$and $\mathrm{Ca}^{++}$by inhibiting ion channels.

Taurine is also known to act as an organic osmolyte. Organic osmolytes are involved in regulatory mechanisms of cell volume decrease and increase (Warskulat et al., 1997). It is reported that osmolyte uptake and osmolyte transporter mRNA are increased by hyperosmotic exposure in several tissues (Warskulat et al., 1997; Satsu et al., 1999; Shioda et al., 2002). However, the hyperosmotic responses to taurine uptake in osteoblast cells have not been previously investigated. Therefore the effect of hyperosmotic conditions (by addition of $100 \mathrm{mM}$ raffinose) on $\left[{ }^{3} \mathrm{H}\right]$ taurine uptake activity was examined. Under hyperosmotic conditions, $\left[{ }^{3} \mathrm{H}\right]$ taurine uptake was increased at 24 hours in both ST2 and MC3T3-E1 cells, though decreased up to 12 hours (Fig. 4). To determine whether the expression of TauT mRNA was induced or not by hyperosmotic conditions, the semi-quantitative analysis was performed. The TauT mRNA level was markedly higher in ST2 and MC3T3-E1 when exposed to hyperosmotic conditions (Fig. 3). It was obvious that TauT mRNA expression level and taurine uptake was increased under hyperosmotic condition in these osteo-

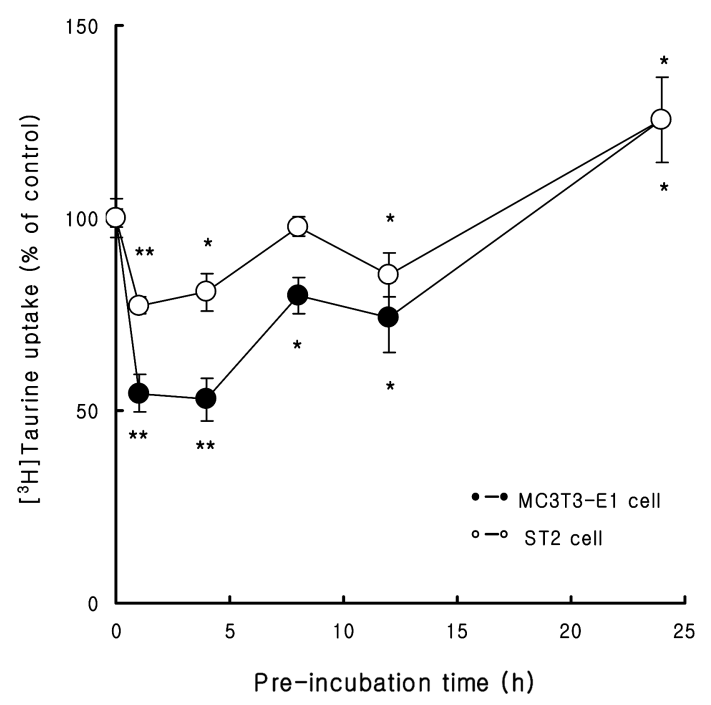

Fig. 4. Time-course of the effect in hypertonic conditions for $24 \mathrm{hrs}$ on $\left[{ }^{3} \mathrm{H}\right]$ taurine uptake at ST2 and MC3T3-E1 cells. Cells were treated with $100 \mathrm{mM}$ raffinose. Each point represents the mean \pm SEM $(n=4)$. ${ }^{*} P<0.01$, ${ }^{* *} P<0.001$; significantly different from the time $=0$.

blast cell lines as well as other tissues. Taurine uptake by pre-treament for 24 hours shows more decrease than that for 12 hours, and it is because of decrease in TauT expression. However, there are needs for more reviews for other factors that may have the effect on decrease of uptake.

Next, we examined whether hyperosmotic-induced $\left[{ }^{3} \mathrm{H}\right]$ taurine uptake was inhibited by L-type calcium channel blockers (Fig. 6). Nifedipine and verapamil also inhibited 


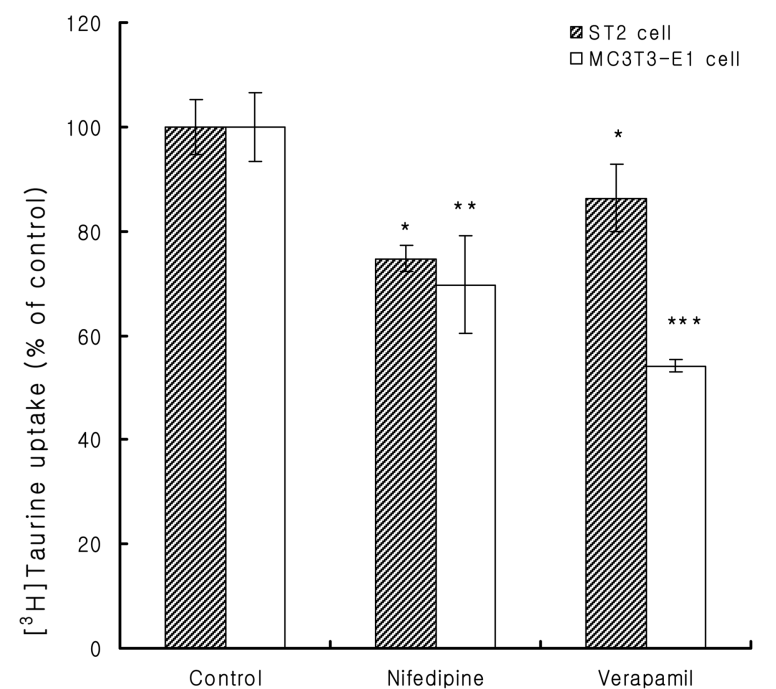

Fig. 5. $\left[{ }^{3} \mathrm{H}\right]$ Taurine $(41.3 \mathrm{nM})$ uptake was $37^{\circ} \mathrm{C}$ for 5 min under calcium channel blockers conditions. Each value represents the mean \pm SEM $(n=4)$. ${ }^{*} P<0.05,{ }^{* *} P<0.01,{ }^{\star * *} P<0.001$; significantly different from control.

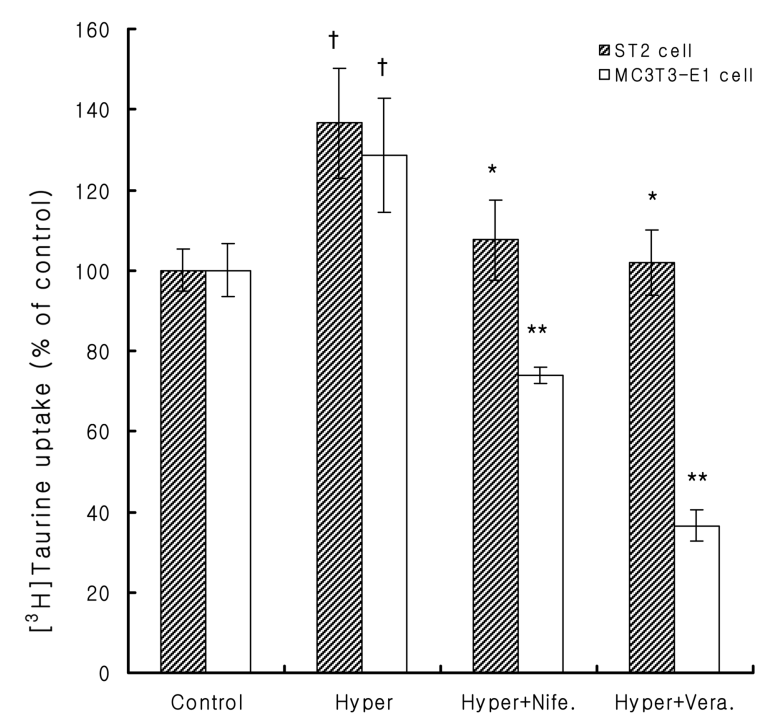

Fig. 6. Effect of calcium channel blockers on-induced $\left[{ }^{3} \mathrm{H}\right] \mathrm{tau}-$ rine uptake was performed at $37^{\circ} \mathrm{C}$ for 5 min under hyperosmotic conditions, $100 \mu \mathrm{M}$ nifedipine and $100 \mu \mathrm{M}$ verapamil as calcium channel blockers with hyperosmotic conditions. Each point represents the mean $\pm \operatorname{SEM}(n=3)$. $+P<0.01$; significantly different from control.

${ }^{*} \mathrm{P}<0.05$, ${ }^{*} \mathrm{P}<0.01$; significantly different from hyperosmotic value.

the hyperosmotic-induced $\left[{ }^{3} \mathrm{H}\right]$ taurine uptake compared with control. It is reported that taurine uptake induced by hyperosmotic pressure is inhibited by $\mathrm{Ca}^{++} /$calmodulindependent protein kinase II inhibitor in human Caco-2 cell
(Satsu et al., 2004). In this study, decrease in taurine uptake by $\mathrm{Ca}^{++}$channel blockers is supposed that, channel blocker inhibits the effects of $\mathrm{Ca}^{++}$on $\mathrm{CaM}$ as $\mathrm{Ca}^{++}$ dependent taurine uptake and then TauT expression is decreased. The effect of $\mathrm{Ca}^{++}$and calcium channel blocker on taurine uptake showed similar behavior between ST2 and MC3T3-E1 cells although some difference was observed. Therefore, our results suggested that $\mathrm{Ca}^{++}$regulated taurine uptake in osteoblast cells.

Moreover, taurine uptake in osteoblast cell lines was regulated by $\mathrm{Ca}^{++}$and the L-type calcium channel blocker, although some differences were observed between ST2 and MC3T3-E1 cells. Furthermore taurine uptake in osteoblast cells was regulated by hyperosmotic conditions accompanied by the change in expression level of TauT mRNA. In this condition taurine uptake was inhibited by calcium inhibitors. These results suggested that taurine uptake into the osteoblast cells contribute to bone formation is regulated by various factors. Also, although there are some differences compared to ST2 and MC3T3-E1 cells, it is considered that there may be some relationship with bone formation or bone absorption modulated by diverse factors such as $\mathrm{Ca}^{++}, \mathrm{H}_{2} \mathrm{O}_{2}$ and LPS.

\section{ACKNOWLEDGEMENTS}

This work was supported by the SRC Research Center for Women's Diseases of Sookmyung Women's University (2008). Also the authors wish to thank Dr. E. Nakashima for the valuable discussion and N. Ishido for her technical assistance in the experiments.

\section{REFERENCES}

Chang, R.C., Stadlin, A., and Tsang, D. (2001) Effects of tumor necrosis factor alpha on taurine uptake in cultured rat astrocytes. Neurochem Int. 38, 249-254.

Chung, IY. and Benveniste, E.N. (1990) Tumor necrosis factoralpha production by astrocytes. Induction by lipopolysaccharide, IFN-gamma and IL-1 beta. J Immunol. 144, 2999-3007.

Della, C.L., Crichton, R.R, Duburs, G. Nolan, K., Tipton, K.F., Tirzitis, G., and Ward, R.J. (2002) The use of taurine analogues to investigate taurine functions and their potential therapeutic applications. Amino Acids 23, 367-379.

El Idriss, i A., and Trenkner, E. (2004) Taurine as a modulator of excitatory and inhibitory neurotransmission. Neurochem Res. 29, 189-197.

El-Sherbeny, A., Naggar, H., Miyauchi, S., Ola, M.S., Maddox, D.M., Martin, P.M., Ganapathy, V., and Smith, SB. (2004) Osmoregulation of taurine transporter function and expression in retinal pigment epithelial, ganglion, and muller cells. Invest Ophthalmol Vis Sci. 45, 694-701. 
Huxtable, R.J. (1992) Physiological actions of taurine. Physiol Rev. 72, 101-163.

Kim H.W., Kim J.H., An H.S., Park K.K., Kim B.K. and Park T. (2003) Myo-inositol restores the inflammation-induced downregulation of taurine transport by the murine macrophage cell line, RAW 264.7. Life Sci. 73, 2477-2489.

Koide, M., Okahashi, N., Tanaka, R., Kazuno, K., Shibasaki, K., Yamazaki, Y., Kaneko, K., Ueda, N., Ohguchi M., Ishihara, Y., Noguchi, T., and Nishihara, T. (1999) Inhibition of experimental bone resorption and osteoclast formation and survival by 2-aminoethaesulphonic acid. Arch Oral Biol. 44, 711-719.

Kang, Y.S., Ohtsuki, S., Takanaga, H., Tomi, M., Hosoya, K., Terasaki, T. (2002) Regulation of taurine transport at the blood-brain barrier by tumor necrosis factor-a, taurine and hypertonicity. J. Neurochem. 83, 1188-1195.

Kourie, J.I. (1998) Interaction of reactive oxygen species with ion transport mechanisms. Am J Physiol. 275, C1-24.

Li, G., Liu, Y., and Olson, J.E. (2002) Calcium/calmodulin-modulated chloride and taurine conductances in cultured rat astrocytes. Brain Res. 925, 1-8.

Lubec, B., Ya-hua, Z., Pertti, S., Pentti, T., Kitzmuller, E., and Lubec, G. (1997) Distribution and disappearance of the radiolabeled carbon derived from L-arginine and taurine in the mouse. Life Sci. 60, 2373-2381.

Masanori, K., Nobuo, O., Rumi, T. (1999) Inhibition of experimental bone resorption and osteoclast formation and survival by 2-aminoethanesulforic acids. Arch Oral Biol. 44, 711-719.

Militante, J.D. and Lombardini, J.B. (1999) Stimulatory effect of taurine on calcium ion uptake in rod outer segments of the rat retina is independent of taurine uptake. J Pharmacol Exp Ther. 291, 383-389.

Mochizuki, T., Satsu, H., and Shimizu, M. (2002) Tumor necrosis factor alpha stimulates taurine uptake and transporter gene expression in human intestinal Caco-2 cells. FEBS Lett. 517, 92-96.

Molchanova, S.M., Oja S.S., and Saransaari, P. (2005) Mechanisms of enhanced tautrine release under $\mathrm{Ca}^{++}$depletion. Neuchem int. 47, 343-349.

Otsuka, E., Yamaguchi, A., Hirose, S., and Hagiwara, H. (1999) Characterization of osteoblastic differentiation of stromal cell line ST2 that is induced by ascorbic acid. Am J Physiol. 277,
C132-138.

Park, S., Kim, H., and Kim, SJ. (2001) Stimulation of ERK2 by taurine with enhanced alkaline phosphatase activity and collagen synthesis in osteoblast-like UMR-106 cells. Biochem Pharmacol. 62, 1107-1111.

Pavalko, F.M., Gerard, R.L., Ponik, S.M., Gallagher, P.J., Jin, Y., and Norvell, S.M. (2003) Fluid shear stress inhibits TNFalpha-induced apoptosis in osteoblasts: a role for fluid shear stress-induced activation of PI3-kinase and inhibition of caspase-3. J Cell Physiol. 194, 194-205.

Satsu, H., Manabe, M., and Shimizu, M. (2004) Activation of $\mathrm{Ca}^{2+} /$ calmodulin-dependent protein kinase II is involved in hyperosmotic induction of the human taurine transporter. FEBS Lett. 569, 123-128.

Satsu, H., Miyamoto, Y., and Shimizu, M. (1999) Hypertonicity stimulates taurine uptake and transporter gene expression in Caco-2 cells. Biochim Biophys Acta. 1419, 89-96.

Shioda, R., Reinach, P.S., Hisatsune, T., and Miyamoto, Y. (2002) Osmosensitive taurine transporter expression and activity in human corneal epithelial cells. Invest Ophthalmol Vis Sci. 43, 2916-2922.

Subramanian, S. and Handa, R. (2004) Biological agents in rheumatoid arthritis. J Postgrad Med. 50, 293-299.

Takeuchi, K., Toyohara, H., and Sakaguchi, M. (2000) A hyperosmotic stress-induced mRNA of carp cell encodes $\mathrm{Na}\left({ }^{+}\right)$and $\mathrm{Cl}\left({ }^{-}\right)$-dependent high affinity taurine transporter. Biochim Biophys Acta. 1464, 219-230.

Warskulat, U., Reinen, A., Grether-Beck, S., Krutmann, J., and Haussinger, D. (2004) The osmolyte strategy of normal human keratinocytes in maintaining cell homeostasis. $J$ Invest Dermatol. 123, 516-521.

Warskulat, U., Wettstein, M., and Haussinger, D. (1997) Osmoregulated taurine transport in H4IIE hepatoma cells and perfused rat liver. Biochem J. 321 (Pt 3), 683-690.

Wersinger, C., Lelong-Rebel, I.H., and Rebel, G. (2001) Sensitivity of taurine uptake to oxygen-derived reactive substances in MDR and non-MDR cells. Amino Acids. 21, 91-117.

Yamauchi, A., Uchida, S., Kwon, HM., Preston, AS., Robey, R.B., Garcia-Perez, A., Burg, M.B., and Handler, JS. (1992) Cloning of a $\mathrm{Na}(+)$ - and $\mathrm{Cl}(-)$-dependent betaine transporter that is regulated by hypertonicity. J Biol Chem. 267, 649-652. 